\title{
A DESCRIÇÃO LINGUÍSTICA E SUA ABORDAGEM NO ENSINO DA LÍNGUA ESPANHOLA
}

\author{
LA DESCRIPCIÓN LINGÜÍSTICA Y SU ABORDAJE EN LA ENSEÑANZA DE LA \\ LENGUA ESPAÑOLA
}

\author{
THE LINGUISTIC DESCRIPTION AND ITS APPROACH IN SPANISH LANGUAGE \\ TEACHING
}

Adriana MARTINS SIMÕES ${ }^{1}$

RESUMO: O objetivo deste trabalho é apresentar reflexões sobre a abordagem da descrição linguística no ensino da língua espanhola, tendo em vista as perspectivas teóricas gerativa (CHOMSKY, 1981; 1986) e sociolinguística (WEINREICH; LABOV; HERZOG, 2009). Para tanto, apresentaremos os resultados iniciais da pesquisa que estamos desenvolvendo sobre o objeto pronominal acusativo de $3^{\mathrm{a}}$ pessoa na variedade de espanhol de Madri e no português brasileiro e reflexões sobre o ensino da língua espanhola. Nossa ideia é de que os avanços na descrição linguística e sua abordagem no ensino a partir dessas perspectivas teóricas possam levar o aluno à reflexão sobre o funcionamento do espanhol e à compreensão dos fatores linguísticos e sociais que estão envolvidos no processo de variação linguística.

PALAVRAS-CHAVE: Espanhol. Objeto pronominal acusativo. Gramática gerativa. Sociolinguística. Ensino de espanhol como língua estrangeira.

RESUMEN: Este trabajo tiene por objetivo presentar reflexiones sobre el abordaje de la descripción lingüística en la enseñanza de la lengua española, teniendo en cuenta las perspectivas teóricas generativa (CHOMSKY, 1981; 1986) e sociolingüistica (WEINREICH; LABOV; HERZOG, 2009). Para ello, presentaremos los resultados iniciales de la investigación que estamos llevando a cabo sobre el objeto pronominal acusativo de $3^{a}$ persona en la variedad de español de Madrid y en el portugués brasileño y reflexiones sobre la enseñanza de la lengua española. La idea es de que los avances en la descripción lingüistica y su abordaje en la enseñanza a partir de esas perspectivas teóricas puedan llevar al alumno a la reflexión sobre el funcionamiento del español y a la comprensión de los factores lingüísticos y sociales que están involucrados en el proceso de variación lingüistica.

PALABRAS CLAVE: Español. Objeto pronominal acusativo. Gramática generativa. Sociolingüística. Enseñanza de español como lengua extranjera.

ABSTRACT: The aim of this paper is to present reflections on linguistic description approach in Spanish language teaching, regarding generative (CHOMKY, 1981; 1986) and sociolinguistic (LABOV, 2008; WEINREICH; LABOV; HERZOG, 2009) theoretical

${ }^{1}$ Universidade Federal de Alfenas (UNIFAL), Alfenas - MG - Brasil. Docente do Departamento de Letras. Doutorado em Letras (USP). ORCID: https://orcid.org/0000-0003-2911-8873. E-mail: adriana.simoes@unifalmg.edu.br 
perspectives. For this, we will present the initial results of the research that we are developing about the $3^{\text {rd }}$ person accusative pronominal object in the Spanish variety of Madrid and Brazilian Portuguese and reflections on Spanish language teaching. The idea is that the advances in linguistic description and its approach in teaching considering those theoretical perspectives can conduct the student to reflect on Spanish operation and to understand the linguistic and social contexts that were involved in linguistic variation.

KEYWORDS: Spanish. Accusative pronominal object. Generative grammar. Sociolinguistic. Spanish teaching as language foreign.

\section{Introdução}

O objetivo deste trabalho é demonstrar como os avanços dos estudos descritivos sobre a língua espanhola e sua abordagem no ensino dessa língua, a partir das perspectivas teóricas gerativa (CHOMSKY, 1981; 1986) e sociolinguística (LABOV, 2008; WEINREICH; LABOV; HERZOG, 2009), podem contribuir para a reflexão do aluno sobre o funcionamento do espanhol comparado com o de sua língua materna. Para tanto, primeiro apresentaremos os resultados iniciais da pesquisa que estamos desenvolvendo sobre o objeto pronominal acusativo de $3^{\mathrm{a}}$ pessoa no espanhol e no português brasileiro (doravante $\mathrm{PB}$ ), que é uma continuidade do estudo desenvolvido em nossa tese de doutorado (SIMÕES, 2015). Para realizar a pesquisa, estamos analisando entrevistas da variedade de espanhol de Madri pertencentes ao Proyecto Sociolingüístico para el Estudio del Español de España y de América (PRESEEA) (CESTERO MANCERA et al., 2014) e entrevistas do PB pertencentes ao Projeto História do Português Paulista (PHPP) (LIMA-HERNANDES; VICENTE, 2012) e ao Programa de Estudos sobre o Uso da Língua (PEUL), desenvolvido na UFRJ. Como referencial teórico, adotamos a concepção biológica de língua (CHOMSKY, 1981; 1986) aliada à sociolinguística (LABOV, 2008; WEINREICH; LABOV; HERZOG, 2009). Considerando-se os estudos sobre o espanhol (CAMPOS, 1986; FERNÁNDEZ SORIANO, 1999; GROPPI, 1997; LANDA, 1993; SUÑER; YÉPEZ, 1988), o PB (CYRINO, 1994; DUARTE, 1986) e os resultados de nossa tese (SIMÕES, 2015), partimos da hipótese de que, na variedade de espanhol de Madri, os objetos nulos seriam favorecidos por antecedentes com o traço semântico de indefinitude, os [animados] e [-específicos]. Por outro lado, no PB, essa elipse seria favorecida por antecedentes com os traços semânticos de indefinitude, definitude, os [-animados] e [+/-específicos] e haveria restrições ou impossibilidade de realização do pronome lexical com antecedentes [animados; -específicos] indefinidos ou quantificados. Em um segundo momento deste trabalho, apresentaremos reflexões sobre nossa experiência no ensino da língua espanhola na 
Universidade Federal de Alfenas, orientado, conforme vimos, também pelas perspectivas teóricas gerativa (CHOMSKY, 1981; 1986) e sociolinguística (LABOV, 2008; WEINREICH; LABOV; HERZOG, 2009), além de nos apoiarmos nas reflexões de Kulikowski (2015) e de Celada e González (2015), que resgatam a história do ensino do espanhol no Brasil.

Este artigo se organiza da seguinte forma: na primeira seção, apresentaremos os principais conceitos das teorias gerativa (CHOMSKY, 1981; 1986) e sociolinguística (LABOV, 2008; WEINREICH; LABOV; HERZOG, 2009); na segunda seção, que se subdivide em três subseções, discutiremos os trabalhos sobre o espanhol e o PB, parte dos resultados de nossa pesquisa de doutorado (SIMÕES, 2015), bem como apresentaremos a metodologia e os resultados iniciais de nossa atual pesquisa; na terceira seção, apresentaremos nossas reflexões sobre o ensino da língua espanhola; finalizaremos com algumas considerações finais.

\section{As perspectivas teóricas gerativa e sociolinguística}

Em nossa atual pesquisa, nos apoiamos na perspectiva biológica de língua (CHOMSKY, 1981; 1986) combinada a alguns aspectos da sociolinguística (LABOV, 2008; WEINREICH; LABOV; HERZOG, 2009). Embora antagônicas, ambas as teorias se mostraram fundamentais para a interpretação dos resultados de nossa pesquisa anterior (SIMÕES, 2015), de modo que mantemos essas duas perspectivas teóricas na análise de nosso estudo atual ${ }^{2}$. Além disso, neste artigo, tecemos reflexões sobre o ensino da língua espanhola orientado sob essas teorias.

\section{A teoria gerativa}

De acordo com Chomsky $(1981 ; 1986)$, os seres humanos seriam dotados de uma capacidade linguística inata, denominada 'Faculdade da Linguagem'. Esse dispositivo, presente na mente/cérebro, seria responsável pelo desenvolvimento do conhecimento linguístico, que, por sua vez, é adquirido mediante a interação entre os dados linguísticos do ambiente e a 'Gramática Universal', que abriga os princípios universais das línguas naturais. A partir desse processo ocorreria a fixação de parâmetros.

$\mathrm{O}$ conhecimento linguístico corresponde à 'língua-I', que se caracteriza por ser internalizada, intensional e individual, opondo-se à 'língua-E', que se caracteriza por ser externa e extensional. Além disso, o conhecimento linguístico compreende a 'competência' do

${ }^{2}$ Kato e Tarallo (1986) combinaram essas perspectivas teóricas e obtiveram resultados significativos no estudo do PB. 
falante, que se diferencia do 'desempenho linguístico', denominado performance e que corresponde à língua em uso.

Depois de ocorrer o processo de fixação de parâmetros de uma determinada língua, o falante teria uma 'gramática nuclear', que se origina desse processo natural de aquisição da linguagem. Por outro lado, ao longo da vida, ocorreria uma expansão da gramática nuclear e surgiria a 'periferia marcada', responsável por abrigar os resíduos de mudança linguística e outros fenômenos.

Em nossa pesquisa, consideramos que tanto o clítico como o objeto nulo corresponderiam à língua-I na variedade de espanhol de Madri. Isso significa que essas formas de expressão do objeto acusativo integrariam o conhecimento linguístico internalizado e adquirido naturalmente pelos falantes nativos. Quanto ao $\mathrm{PB}$, o clítico 'o' já não constitui aquisição natural (MAGALHÃES, 2006). Portanto, esse pronome ocorreria apenas na produção de falantes escolarizados (DUARTE, 1986) e, conforme Galves (2001) e Kato (2005), integraria a periferia marcada. Sendo assim, no PB, apenas o objeto nulo e o pronome lexical 'ele' formariam parte da gramática adquirida naturalmente para a expressão do objeto acusativo.

No âmbito do ensino da língua espanhola, ao aplicar a teoria gerativa, nosso objetivo é levar o aluno à reflexão sobre o que seria o conhecimento linguístico internalizado, mediante a percepção do que seria esse conhecimento no âmbito da língua materna, para que, assim, este comece a sensibilizar-se a respeito do funcionamento do espanhol e suas especificidades.

Segundo Lightfoot (2006, p. 89), a língua-E seria um reflexo do output das gramáticas das comunidades linguísticas e do uso da língua no discurso e na variação social. Em nosso estudo, as entrevistas analisadas compreenderiam a língua-E. Por outro lado, os dados de clítico e de elipse do objeto no espanhol, bem como o pronome lexical e a elipse do PB, compreenderiam a língua-I enquanto conhecimento linguístico internalizado. Portanto, embora as entrevistas representem a língua em uso e constituam tanto o conhecimento linguístico internalizado quanto o desempenho linguístico do falante, o objeto de análise de nossa pesquisa compreende a competência linguística.

\section{A teoria sociolinguística}

Conforme Labov (2008), os sistemas linguísticos teriam um caráter heterogêneo, uma vez que as línguas sofrem variação por estarem inseridas em comunidades de fala. A variação compreenderia formas linguísticas equivalentes, que seriam compartilhadas pelos membros de 
uma comunidade de fala, ainda que as frequências de produção de cada forma linguística sejam diferentes em cada um dos falantes.

A variação linguística seria um fenômeno de transição, que se manifestaria devido ao fato de a variante inovadora não poder substituir a outra variante de maneira instantânea. Contudo, existem fenômenos de variação que se estendem por um longo período, os quais se denominam 'variação estável'.

Weinreich, Labov e Herzog (2009) propõem que a variabilidade e a heterogeneidade que se observam nas línguas poderiam não implicar uma mudança em progresso, mas um processo de variação estável. Entretanto, para que ocorra mudança, é necessária a existência da variação.

Para Weinreich, Labov e Herzog (2009), a mudança linguística seria regida por princípios, sendo eles: (1) os fatores condicionantes, que constituem contextos linguísticos e sociais aos quais as formas em variação estariam condicionadas; (2) a transição, que revelaria o processo de mudança linguística em curso; (3) o encaixamento, que, na esfera linguística, se manifesta pela alteração gradual das variantes e, na esfera social, em fatores sociais que estariam relacionados com uma variante ou outra; (4) a avaliação, que constitui a significação social que os falantes atribuem a determinada variante; (5) a implementação, que se manifesta, no âmbito linguístico, de forma gradual pelo sistema e, no âmbito social, a significação de uma variante poderia atuar tanto na sua implementação no sistema quanto no retrocesso da mudança.

Em nossa pesquisa, a variedade de espanhol de Madri e as duas amostras do PB que analisamos constituem diferentes comunidades linguísticas. Nos concentramos em verificar os contextos linguísticos que poderiam favorecer a ocorrência da elipse de objeto no espanhol e a impossibilidade de realização pronominal ou sua presença no PB, para, assim, verificar o encaixamento desse fenômeno de variação na estrutura linguística.

No que se refere ao ensino do espanhol, nosso objetivo ao abordar a gramática dessa língua sob essa perspectiva teórica é levar o aluno a refletir sobre o processo de variação e os fatores linguísticos e sociais que incidem sobre ela.

\section{A descrição linguística do espanhol comparada ao português brasileiro: o objeto pronominal acusativo}

Abordaremos, nesta seção, que se subdivide em três subseções, os trabalhos sobre o objeto pronominal acusativo de $3^{\text {a }}$ pessoa no espanhol, no $\mathrm{PB}$, e os resultados de nossa pesquisa 
de doutorado (SIMÕES, 2015) sobre o tema, para, em seguida, apresentar a metodologia e os resultados de nossa pesquisa atual.

\section{A gramática do espanhol e do português brasileiro}

De acordo com os estudos de Campos (1986) e Fernández Soriano (1999), no espanhol, a elipse do objeto em função acusativa apenas seria possível com antecedentes [-específicos; definidos]. Contudo, nos casos em que o antecedente é [+específico], seria necessária a retomada por um clítico. Conforme Groppi (1997), a variedade de espanhol de Montevidéu apresentaria a mesma tendência. Observem-se as sentenças a seguir:

(1a) - ¿Compraste flores?

- Sí, compré Ø.

— Sí, *las compré.

(1b) - ¿Compraste las flores?

— Sí, compré * $\boldsymbol{\varnothing}$.

— Sí, las compré. [Exemplos extraídos e adaptados de Campos (1999, p. 1530)]

Apesar de o espanhol ser uma língua em que a possibilidade de objetos nulos é altamente restringida, algumas variedades dessa língua apresentam a omissão do objeto em contextos mais amplos, entre elas a variedade falada no País Basco (LANDA, 1993) e em Quito (SUÑER; YÉPEZ, 1988).

Com relação à variedade basca, segundo Landa (1993), a elipse do objeto seria possível com antecedentes [+determinados; +/-definidos] em construções ditransitivas [exemplo (2a)], com antecedente em posição de tópico [exemplo (2b)] e quando o antecedente constitui uma oração [exemplo (2c)].

(2a) También tengo las fotos $\mathrm{s}_{\mathrm{i}}$ del bote de J., pero están muy desenfocadas, así que no os $=\varnothing_{\mathrm{i}}=$ mando $e_{\mathrm{i}}$. Los padres de $\mathrm{J}$. quieren que les $=\varnothing_{\mathrm{i}}=$ mandemos $e_{\mathrm{i}}$, aunque estén desenfocadas, así que me imagino que J. les $=\varnothing_{\mathrm{i}}=$ mandará $e_{\mathrm{i}}$.

(2b) $\quad \mathrm{La}_{\text {boda }} \mathrm{me}=\varnothing_{\mathrm{i}}=$ pagó $e_{\mathrm{i}}$ éste de la Campa de Erandio.

(2c) La madre piensa [que $\mathrm{H}$. va a aprobar todo en septiembre $]_{i}$ pero yo no $\varnothing_{\mathrm{i}}=$ creo $e_{\mathrm{i}}$. (LANDA, 1993, p. 139-140)

No que se refere à variedade de Quito, os objetos nulos ocorreriam com antecedente [+definido] em construções de tópico [exemplo (3a)], quando o antecedente aparece na oração anterior [exemplo (3b)], em construções com o clítico dativo [exemplo (3c)] e quando o antecedente é oracional com todos os tipos de verbos [exemplo (3d)].

(3a) Las elecciones yo nunca entendí Ø.

(3b) A mi mamá se le quedó un poco mal cerrado el armario y logré abrir $\varnothing$.

(3c) Bueno, yo te $\varnothing$ saco. 
$(1 \mathrm{l}=$ el vestido $)$
(3d) No te olvides de decirle. (SUÑER; YÉPEZ, 1988, p. 513)

Com relação ao PB, conforme demonstraram diferentes estudos (CYRINO, 1994; DUARTE, 1986; GALVES, 2001; KATO; TARALLO, 1986; TARALLO, 1993), desde o século XIX essa língua vem passando por um processo de mudança em seu sistema pronominal, que ocasionou a perda do clítico acusativo, a ampliação das possibilidades de objetos nulos, o surgimento do pronome lexical em função acusativa, entre outros fenômenos.

Cyrino (1994) revela que, no PB contemporâneo, os objetos nulos seriam possíveis com antecedentes oracionais e nominais [+/-específicos]. Duarte (1986) verificou a ocorrência de $23,7 \%$ de elipse do objeto com antecedentes [+animados] [exemplo (4a)] e 76,3\% com antecedentes [-animados] [exemplo (4b)]. A partir desses resultados, observamos que os antecedentes [-animados] favoreceriam os objetos nulos no PB.

(4a) A FEBEM é um dos elos dessa corrente que cria o menor infrator; não é ela o único responsável, o único elo que cria (e), e como tal ela não consegue recuperar (e). (entrevista) $(46,47)$

(4b) O Armando leu a peça e aprovou (e). (novela) (123) (DUARTE, 1986, p. 16)

Apesar de em seus dados Cyrino (1994) não ter encontrado a omissão do objeto com antecedentes [+animados; +específicos], conforme Kato (2003), essa categoria vazia poderia referir-se a um antecedente [+humano] se este ocorrer em posição de tópico, como se observa em (5).

(5) Esse atori, eu acho que (eu) não conheci $\emptyset_{\text {i. }}$ (KATO, 2003, p. 139)

Por fim, no que se refere ao pronome lexical, segundo Kato (2002), em decorrência da perda de restrição de antecedentes [+humanos], esse pronome poderia retomar uma entidade [humana], como se observa em (6), construção na qual o pronome se refere ao sintagma nominal (doravante $\mathrm{SN}$ ) o carro.

(6) Se tiver muita pressa, eu largo ele num lugar proibido mesmo (SP). (GALVES, 2001, p. 163)

Passaremos agora a apresentar parte dos resultados de nossa pesquisa de doutorado (SIMÕES, 2015) sobre a realização do objeto pronominal acusativo de $3^{\mathrm{a}}$ pessoa nas variedades de espanhol de Madri e Montevidéu comparada ao PB, da qual partimos para desenvolver nossa pesquisa atual. 
Considerando-se os estudos de Campos (1986), Fernández Soriano (1999) e Groppi (1997), nossa hipótese era de que nas variedades de espanhol de Madri e Montevidéu a omissão do objeto se restringiria a antecedentes [-determinados; -específicos].

Ao analisar as entrevistas orais dessas variedades de espanhol, observamos a ocorrência de $95,9 \%$ de clíticos para expressar antecedentes nominais e 4,1\% de elipse do objeto na variedade de Madri. Quanto à variedade de Montevidéu, observamos que esses índices correspondem a $88,9 \%$ e $11,1 \%$, respectivamente. Verificamos que os objetos nulos não se restringiram aos antecedentes [-determinados; -específicos], já que encontramos essa categoria vazia com antecedentes $[+ \text { determinados; }+/ \text {-específicos }]^{3}$. Esses resultados revelam que nossa hipótese foi parcialmente contrariada.

Constatamos que os objetos nulos foram favorecidos pelos SNs sem determinante, os introduzidos por um quantificador, pelo artigo indefinido, os [-animados] e, na variedade de Montevidéu, também os [-específicos]. Observem-se as tabelas a seguir:

Tabela 1 - Objetos nulos nominais conforme a estrutura do SN antecedente nas variedades de espanhol de Madri e Montevidéu

\begin{tabular}{l|l|l|l|l|l|l}
\hline & \multicolumn{3}{|c|}{ Variedade de Madri } & \multicolumn{3}{c}{ Variedade de Montevidéu } \\
\cline { 2 - 7 } & n./total & $\%$ & p. relativo & n./total & $\%$ & p. relativo \\
\hline Det. Def & $21 / 733$ & $2,9 \%$ & 0,45 & $33 / 630$ & $5,2 \%$ & 0,40 \\
\hline Art. ind. & $7 / 158$ & $4,4 \%$ & 0,55 & $16 / 108$ & $14,8 \%$ & 0,68 \\
\hline Quant. & $4 / 74$ & $5,4 \%$ & 0,57 & $10 / 72$ & $13,9 \%$ & 0,54 \\
\hline SN s/ det. & $11 / 84$ & $13,1 \%$ & 0,78 & $41 / 89$ & $46,1 \%$ & 0,86 \\
\hline
\end{tabular}

Fonte: adaptada de Simões (2015, p. 138)

Tabela 2 - Objetos nulos nominais conforme a animacidade e especificidade do SN antecedente nas variedades de espanhol de Madri e Montevidéu

\begin{tabular}{|c|c|c|c|c|c|c|}
\hline & \multicolumn{3}{|c|}{ Variedade de Madri } & \multicolumn{3}{|c|}{ Variedade de Montevidéu } \\
\hline & n./total & $\%$ & p. relativo & n./total & $\%$ & p. relativo \\
\hline [+an.] & $3 / 274$ & $1,1 \%$ & 0,26 & $17 / 372$ & $4,6 \%$ & 0,31 \\
\hline [-an.] & $40 / 775$ & $5,2 \%$ & 0,59 & $83 / 527$ & $15,7 \%$ & 0,64 \\
\hline [+esp.] & $14 / 406$ & \multicolumn{2}{|c|}{$3,4 \%$} & $10 / 411$ & $2,4 \%$ & 0,30 \\
\hline [-esp.] & $29 / 643$ & \multicolumn{2}{|c|}{$4,5 \%$} & $90 / 488$ & $18,4 \%$ & 0,68 \\
\hline
\end{tabular}

Fonte: adaptada de Simões (2015, p. 145-148)

Com relação aos antecedentes que constituem SNs sem determinante, atribuímos o resultado de nossa pesquisa à incompatibilidade entre o clítico, que é um pronome

\footnotetext{
${ }^{3}$ Tendo em vista que nosso objetivo era verificar os contextos que favoreceriam a omissão do objeto, a variante 'objeto nulo' foi escolhida como o valor de aplicação da regra variável. Na variedade de Madri, foram selecionados como significativos para a ocorrência de objeto nulo e, conforme a relevância, o traço semântico de animacidade e a estrutura do SN antecedente. Quanto à variedade de Montevidéu, foram selecionados a estrutura do SN e os traços semânticos de animacidade e especificidade.
} 
definido, e esse tipo de SN, que não constitui uma expressão referencial (cf. DI TULLIO, 1997).

Quanto aos SNs quantificados e indefinidos, conforme Leonetti (1999), esses determinantes apresentam o traço semântico de indefinitude, que se caracteriza por não identificar o referente. Sendo assim, atribuímos a tendência encontrada a essa característica.

Por fim, no que concerne aos antecedentes [-animados] e [-específicos], segundo a proposta de Cardinaleti e Starke (1994), abordada em Cyrino, Duarte e Kato (2000), seriam essas entidades que se encontrariam na extremidade menos referencial da escala e que teriam mais probabilidade de expressar-se anaforicamente sem realização fonética. Por outro lado, as entidades [+animadas] e/ou [+específicas] estariam na extremidade mais referencial e a tendência seria que se expressassem mediante um pronome. Portanto, os resultados encontrados em nossa pesquisa se devem a essa gradação na referencialidade.

Vejamos alguns dados de objetos nulos encontrados nas variedades de espanhol de Madri e Montevidéu. Nas construções em (7), temos a omissão do objeto com SNs sem determinante; em (8) e (9), os antecedentes constituem SNs quantificados e indefinidos, respectivamente; e, em (10), temos SNs que são [-animados] e também [-específicos].

(7a) E: y los estudios ¿seguirías con la idea de hacer oposiciones o no?

I: yo creo que sí porque yo creo que en mi casa aburrida / o a lo mejor no haría $\emptyset$ / yo realmente hago oposiciones para tener un trabajo seguro / [...] (Entrevista 5 - Madri)

(7b) E: y en el jardín ¿tenés plantas?

I: sí / en el fondo tenemos Ø sí / ahora / [...] (Entrevista 17 - Montevidéu)

(8a) I: [...] bueno llevaba en el bolsillo dos mi<alargamiento/>l y algo / hh si le llego a dar Ø a mi hijo / pues el tío sale frustrado del todo ¿comprendes? [...] (Entrevista 16 Madri)

(8b) E: ¿compraste alguna rifa?

I: no / mamá compra $\boldsymbol{\emptyset}$ en la de arquitectura $<$ ruido = "ladrido" $>>($ Entrevista $20-$ Montevidéu)

(9a) I: y<alargamiento/ $>$ no sé / bueno / ee / yo hace tiempo lo pensaba y un una mercería que hay un poquito más abajo<alargamiento/> la traspasaron menos mal / porque iban cerrando Ø [...] (Entrevista 4 - Madri)

(9b) I: nunca he llegado al $<$ risas $=$ "todos" $/>/$ este $<$ alargamiento $/>/$ cuando llegué a los $/$ a unos cubiertos creo que tenía Ø Devoto / [...] (Entevista 1 - Montevidéu)

(10a) I: [...] aparte no me complico en el cocido la $<$ alargamiento/>rgo $\boldsymbol{\emptyset}$ en plan de Lardi ni<alargamiento/> ni pollo ni gallina [...] (Entrevista 12 - Madri)

(10b) I: eran más definidas las estaciones ¿no? absolutamente / es más eh uno asociaba Ø a los juegos / la cometa por ejemplo / [...] (Entrevista 13 - Montevidéu)

Observamos também a ocorrência de objetos nulos em contextos que favorecem essa omissão nas variedades de espanhol do País Basco (LANDA, 1993), de Quito (SUÑER; YÉPEZ, 1988) e no PB (CASAGRANDE, 2012; DUARTE, 1986), mas que, em nossa 
pesquisa, não foram selecionados como relevantes para a ocorrência da elipse. Esses contextos compreendem as construções com aspecto [-perfectivo], com perífrase verbal, clítico dativo, predicação secundária, tópico e verbos cognitivos. Observem-se alguns dados:

(11a) I: los más modestos del barrio somos los que procedemos / hh de esa<alargamiento/ $>$ etapa / que nos adjudicaron / los los pisos que $<$ alargamiento/ $>$ nos tocaron / no $<$ alargamiento/ $>$ había opción de decir $<$ cita $>$ yo quiero $\boldsymbol{\emptyset}$ en esta calle en esta altura [...] (Entrevista 18 - Madri)

(11b) I: [...] no sé de qué será esa sal // a mí me han regalado Ø tengo ahí un poco pero bueno / [...] (Entrevista 13 - Madri)

(11c) I: sí / una plazoleta chiquitita / estee / 21 de Setiembre / se engancha con Bulevar España por ahí / a una de ellas / violaron Ø / eran las seis de la mañana (Entrevista 9 Montevidéu)

(11d) I: [...] mi madre así < vacilación/> no se compraba un helado en la heladería <cita > porque Miguel no / porque / nos ayuda / y tú sabes que no / yo te hago $\boldsymbol{\varnothing}$ en casa de lo que tú quieras / de chocolate / de crema / pero un helado de heladería no te puedo comprar $\boldsymbol{\varnothing}</$ cita $>$ [...] (Entrevista 14 - Montevidéu)

(11e) E: ¿y tienen una comida típica para Navidad o van cambiando el menú?

I: no vamos cambiando $\boldsymbol{\varnothing}$ de acuerdo al estado de ánimo de $<$ alargamiento/ $>1$ que recibe / [...] (Entrevista $11-$ Montevidéu)

Em relação à comparação que realizamos entre as variedades de espanhol de Madri e Montevidéu e o PB, mediante a tradução para essa língua de alguns casos de objetos nulos encontrados nessas variedades de espanhol, verificamos que, com antecedentes [+animados; +específicos], seja o SN definido ou indefinido, seria possível a variação entre a categoria vazia e o pronome lexical [exemplos (12)]. Essa possibilidade de variação se mantém entre os antecedentes [+animados; -específicos], seja o SN definido ou quantificado [exemplos (13)].

(12a) [...] este espera que eu te mostro Ø/ele [...] (referente: o filho da informante) (cf. entrevista 16 - Madri)

(12b) uma amiga minha eu chamei Ø/ela quando ela estava vendo TV para dedicar um vídeo para ela $[. .$.$] (cf. entrevista 5$ - Madri)

(13a) porque a polícia nós não chamamos Ø/ela porque eles não tinham entrado... não tinham roubado nada [...] (cf. entrevista 18 - Montevidéu)

(13b) A: e você considera que tem alguns amigos?

B: sim... E é uma

A: ah... $\operatorname{sim}$

B: está bom então

A: por sorte eu encontrei Ø/eles/alguns... viu? [...] (cf. entrevista 2 - Montevidéu)

No âmbito dos antecedentes [-animados; +específicos], a variação entre a elipse e o pronome ocorreria com os SNs definidos e indefinidos. Por outro lado, com os SNs quantificados, seria possível apenas a omissão do objeto.

(14a) [...] eu não sei do que é esse sal... me deram Ø/ele... eu tenho um pouco aí [...] (cf. entrevista 13 - Madri) 
(14b) com uma barrinha de ferro que introduzia em uma tábua... eu tenho Ø/ela lá naquele quarto... depois eu te mostro Ø/ela [...] (cf. entrevista 12 - Montevidéu)

(14c) [...] eu levava no bolso dois mil e alguma coisa... se eu chego a dar $\mathbf{\emptyset} / *$ ele para o meu filho... o cara sai frustrado de tudo... entende? [...] (cf. entrevista 16 - Madri)

Quanto aos antecedentes [-animados; -específicos], quando o SN é introduzido por determinante definido, a variação entre o objeto nulo e o pronome seria possível em construções com verbos dinâmicos [exemplo (15a)]. Entretanto, em construções com verbos estativos, o pronome levaria a uma interpretação [+específica] do antecedente [exemplo (15b)]. Na esfera dos SNs indefinidos, o pronome seria aceito em uma construção com verbo dinâmico, mas não seria aceito se o antecedente aparece como tópico [exemplo (15c)]. Quando se trata de construção com verbo estativo, o pronome não seria possível [exemplo (15d)]. Por fim, com SNs quantificados, a expressão pelo pronome seria aceita com o quantificador muitos [exemplos (15e) e (15f)].

(15a) [...] no arroz... por exemplo... no arroz... primeiro eu refogo $\emptyset$ /ele com óleo e cebola [...] (cf. entrevista 8 - Madri)

(15b) [...] recebemos os apartamentos e não era possível dizer "eu quero Ø/ele nesta rua nesta altura" [...] (cf. entrevista 18 - Madri)

(15c) [...] minha mãe não comprava um sorvete na sorveteria... "porque Miguel nos ajuda e você sabe que não... eu te faço Ø/ele em casa do que você quiser... de chocolate... de creme... mas um sorvete de sorveteria eu não posso te comprar $\emptyset /$ ?ele" [...] (cf. entrevista 14 - Montevidéu)

(15d) A: e com ela você tem uma boa relação?

B: como eu tinha $\boldsymbol{\varnothing} /$ ?ela com o meu irmão... como eu tenho $\emptyset /$ ?ela com a minha cunhada [...] (cf. entrevista 8 - Montevidéu)

(15e) [...] depois que está tudo frito... eu misturo Ø/?ele... agrego Ø/?ele à massa [...] (cf. entrevista 3 - Madri)

(15f) A: [...] pois eu tenho muitos exames muitos atestados de incapacidade que refazer é muito difícil

B: é verdade... é uma confusão... vai muito tempo

A: e só eu poderia fazer $\emptyset /$ eles / porque meus filhos não fizeram Ø/eles (cf. entrevista 18 - Madri)

Para finalizar esta subseção, sintetizaremos os principais aspectos apresentados.

A partir dos trabalhos de Campos (1986), Fernández Soriano (1999) e Groppi (1997), verificamos que, no espanhol, os objetos nulos se restringiriam a antecedentes que constituem SNs sem determinante, enquanto no espanhol falado no País Basco (LANDA, 1993) e em Quito (SUÑER; YÉPEZ, 1988) é possível a omissão do objeto com SNs determinados.

Contudo, encontramos em nosso estudo (SIMÕES, 2015) a omissão do objeto não apenas com antecedentes [-determinados], mas também [+determinados], sendo essa categoria vazia favorecida por SNs que apresentam o traço semântico de indefinitude, seja pela ausência de determinante ou por estarem introduzidos por quantificador ou o artigo indefinido. A 
omissão também foi favorecida por antecedentes que seriam menos referenciais e teriam, portanto, maior probabilidade de expressar-se mediante uma elipse. Além disso, os objetos nulos nas variedades de espanhol investigadas ocorreram em construções que favorecem essa omissão nas variedades de espanhol em que esta ocorre em contextos mais amplos.

Apesar de o espanhol não se configurar como uma língua de objetos nulos, os resultados de nossa pesquisa (SIMÕES, 2015) poderiam revelar os caminhos que as línguas naturais percorrem no que se refere à expressão do objeto por uma categoria elíptica. Nesse sentido, seria reveladora a omissão do objeto que encontramos durante a leitura de um livro de literatura infanto-juvenil em francês, como se observa em (16).

(16) On a cherché autre chose à faire et Agnan m'a dit que pour étudier les sciences, son papa lui avait offert un jeu de chimie. Il m'a montré $\boldsymbol{O}$ et c'est très chouette. (Le petit Nicolas, p. 139)

A gente procurou outra coisa para fazer e Agnan me disse que para estudiar ciência, seu papai tinha dado para ele um jogo de química. Ele me $\boldsymbol{\emptyset}$ mostrou. É muito legal. (SIMÕES, 2015, p. 247)

Observamos que essa construção com objeto nulo apresenta o verbo cognitivo montrer e o clítico dativo em função de objeto indireto, que são contextos relacionados à omissão do objeto no espanhol falado no País Basco (LANDA, 1993) e em Quito (SUÑER; YÉPEZ, 1988). Além disso, embora a construção apresente aspecto perfectivo e o SN antecedente seja [+específico], este ocorre na sentença anterior à elipse, bem como é [-animado] e introduzido pelo artigo indefinido, contextos que, como vimos, favoreceram a omissão do objeto nas variedades de espanhol que investigamos (SIMÕES, 2015).

Quanto ao $\mathrm{PB}$, vimos que, em decorrência do processo de variação e mudança linguística que ocorre nessa língua desde o século XIX, a omissão do objeto seria possível com antecedentes [+/-específicos] (CYRINO, 1994) e, sobretudo, [-animados] (DUARTE, 1986).

Em nossa análise a respeito das possibilidades do PB (SIMÕES, 2015), observamos que a expressão do objeto pelo pronome estaria condicionada a entidades [+animadas] e [+específicas]. No que concerne aos antecedentes [-animados], apenas os SNs [+específicos], definidos ou indefinidos, aceitaram a variação entre o pronome e a elipse em todas as construções. A impossibilidade de expressão por pronome ocorreria quando temos a combinação de antecedente [-animado; -específico], indefinido e construção com verbo estativo. 


\section{Metodologia}

$\mathrm{Na}$ atual pesquisa que desenvolvemos, continuamos analisando como variável a realização do objeto pronominal acusativo de $3^{\mathrm{a}}$ pessoa, sendo as variantes sua expressão por objeto nulo e por pronome, seja o clítico no espanhol e o pronome lexical ou o clítico no PB.

Analisamos entrevistas da variedade de espanhol de Madri ${ }^{4}$ (CESTERO MANCERA et al., 2014) pertencentes ao PRESEEA e entrevistas do PB pertencentes ao PHPP (LIMAHERNANDES; VICENTE, 2012) e ao PEUL.

Investigamos diferentes contextos linguísticos, entre eles a estrutura e os traços semânticos do SN antecedente ${ }^{5}$, o aspecto léxico e a semântica verbal.

\section{Resultados iniciais}

Teceremos, nesta parte, algumas considerações sobre os resultados iniciais de nossa atual pesquisa, que constituem uma análise qualitativa de alguns dos dados encontrados, embora nosso objetivo seja realizar uma análise quantitativa.

Nossa pesquisa atual se justifica pela necessidade de avançarmos na descrição dessa área da gramática do espanhol e do PB, detectando, na esfera do espanhol, as possibilidades de elipse e, na esfera do $\mathrm{PB}$, os contextos nos quais se torna imprescindível um pronome para expressar o antecedente, bem como os contextos em que este não seria possível. Essa pesquisa nos permitiria avançar na compreensão dos mecanismos que atuam na expressão dos argumentos do verbo por pronome ou elipse nas línguas naturais.

Conforme Kany (1969), a omissão do objeto nulo oracional seria possível com verbos de comunicação e cognitivos, inclusive em variedades do espanhol nas quais os objetos nulos nominais seriam restringidos. Conforme vimos, nas variedades de espanhol do País Basco (LANDA, 1993) e de Quito (SUÑER; YÉPEZ, 1988), os antecedentes oracionais possibilitam a elipse do objeto.

Em nossa pesquisa (SIMÕES, 2015), observamos a ocorrência de 11\% de elipse de objeto oracional na variedade de Madri e 31\% na variedade de Montevidéu. Verificamos que a omissão do objeto com antecedente oracional foi favorecida pela semântica verbal, de modo que tanto os verbos de comunicação quanto os cognitivos favoreceram essa omissão.

${ }^{4}$ É provável que em nossa atual pesquisa analisemos também entrevistas da variedade de espanhol de Montevidéu.

${ }^{5}$ Verificamos se se trata de SN definido, indefinido, quantificado ou sem determinante e se apresenta os traços semânticos de especificidade e animacidade. 
Os dados diacrônicos de Cyrino (1996) revelam que a expansão na possibilidade de objetos nulos nominais no PB teria tido origem nos objetos nulos oracionais. Cyrino (1994) constatou que a partir do século XVIII a incidência da elipse com antecedentes oracionais começou a se acentuar e, no século XX, o índice de apagamento do objeto atingiu 90\%.

Encontramos nas entrevistas da variedade de espanhol de Madri que estamos analisando ocorrências de objeto nulo oracional com verbo de comunicação [exemplo (17a)] e cognitivo [exemplo (17b)].

(17a) E: ¿y tú recuerdas si eso también sucedía antes? eeh estos / estas eeh vamos cuando tú eras pequeño/

I: hombre yo / tanto ya no / no sabría decirte Ø pero vamos [...] (Informante 19)

(17b) E: o sea que / o sea que fue que se podía llevar // objetos pesados / el el / ¿sí?

I: eeh hombre yo creo tanto no // pero vamos // cuando estás en esa situación nunca $\underline{\text { sabes } \boldsymbol{\varnothing}} / /($ Informante 19)

No âmbito dos objetos nulos nominais, encontramos elipses com SNs [+/determinados]. Com relação aos SNs [+determinados], estes são introduzidos pelo artigo definido, demonstrativo e artigo indefinido. Até este momento, todos os objetos nulos nominais encontrados constituem entidades [-animadas; -específicas]. Quanto às construções em que essas elipses ocorrem, em (18a) temos uma perífrase com verbo principal no gerúndio e que pode ser classificado como um verbo de comunicação. Na construção em (18b), também ocorre perífrase e o verbo principal constitui um verbo cognitivo, assim como o verbo da construção em (18c). Em (18d), há um verbo dinâmico na primeira ocorrência de omissão do objeto e, na segunda, outra perífrase de gerúndio também com verbo principal de aspecto dinâmico. Por fim, na construção em (18e), temos perífrase modal e o verbo principal se insere entre os de aspecto dinâmico.

(18a) E: ¿qué pasa que es cara esa?

I: no / no es que sea cara // pero vamos es un / el problema que tiene esa moto es que nadie te la arregla ¿no? / o sea tienes que aprender a arreglártela // no es lo mismo que tú llegas con / con otra moto y llegas se te / tienes el concesionario el servicio oficial / es todas las piezas si quieres te vas a una tienda y consigues con una herramienta / o un repuesto / en esto no / en esto te tienes que buscar las habichuelas // y cad / cada dos por tres estás pidiendo Ø fuera $<$ silencio/ $>$ (Informante 19)

(18b) I: en lo que nosotros nos movemos es / pues eso // lo que son las Scooter por // porque es lo que nos gusta y porque sabes apreciar $\boldsymbol{\varnothing}$ realmente (Informante 19)

(18c) I: lo comprenderías ¿no? o bueno / tampoco lo comprenderías ¿no? porque esa violencia / con la que ellos / eeh actuaron pues tampoco // yo es que no lo entiendo o sea no entiendo a la gente que puede ir haciendo

E: es decir porque han mirado mal a / a mi / a mi novia ¿no?

I: no / sí / pero es que no / aun así es que yo no entiendo Ø (Informante 19)

(18d) E: ¿y a la juegas al / a los juegos de azar / la lotería / la quiniela? 
I: eeh / en todo el año / compro el décimo de hoy para la / la lotería de navidad / y porque lo compramos todos en el trabajo / y si a lo mejor estás un día y estamos todos los amigos y viene ya el de la ONCE o algo de eso y compran / compras Ø / pero por el hecho de joder / a ver si les va a tocar a estos que están comprando Ø al lado mío pero a mí por mi o sea [...] (Entrevista 20)

(18e) I: o te vas a vamos / hoy he estado hablando con un compañero mío de del trabajo que se ha cambiado de empresa / y se ha comprado ahora está viviendo / vive en M A por aquí / y se han comprado un / un chalé o algo así / o un adosado en / en Alcalá de Henares / y dice que es que ya estaba viendo que lo que le valía allí / y con lo mismo aquí compraba otro más grande que / y es que de meterte en un chalecito con no sé qué / a meterte en un piso con una habitación de hace cuarenta años pues no / y claro es que aquí no puedes comprarØ de otra manera / y luego // en principio pues / seguir trabajando // tampoco he pensado mucho así en el futuro porqu (Entrevista 20)

Esses resultados iniciais, que nos permitem apenas uma análise qualitativa dos dados, apontam algumas tendências que vão ao encontro dos resultados de nossa pesquisa anterior (SIMÕES, 2015), já que observamos que todos os objetos nulos encontrados até este momento constituem entidades [-animadas; -específicas].

Também nos chama a atenção os contextos estruturais e semânticos das construções em que ocorrem as omissões de objeto. Conforme vimos, esses contextos favorecem a omissão no espanhol basco (LANDA, 1993) e no de Quito (SUÑER; YÉPEZ, 1988). Além disso, os objetos nulos das variedades de Madri e Montevidéu também ocorreram nesses contextos. Esses resultados iniciais sugerem que atua na possibilidade de omissão do objeto não apenas a estrutura do SN antecedente e seus traços semânticos, mas também a estrutura e a semântica do predicado verbal. Já havíamos constatado evidências dessa interação em nossa pesquisa anterior (SIMÕES, 2015).

Em relação ao PB, analisamos 11 entrevistas pertencentes ao PHPP (LIMAHERNANDES; VICENTE, 2012) e que revelam a língua falada culta da variedade de São Paulo.

A partir da análise dessas entrevistas, constatamos a ocorrência quase categórica de objetos nulos e algumas poucas ocorrências de clíticos, porém nenhuma produção do pronome lexical. Diante desse resultado, nossa estratégia para verificar a possibilidade de expressão do objeto pelo pronome lexical no PB consistiu em empregar o pronome e observar se seria possível o seu emprego em cada uma das construções encontradas.

$\mathrm{Na}$ esfera dos SNs quantificados, se o antecedente é [-animado; +específico] e a construção apresenta verbo dinâmico, parece possível a alternância entre a elipse e o pronome [exemplo (19a)]. Contudo, no caso de um antecedente [-animado; +específico], em construção com verbo estativo, o pronome já não seria aceito [exemplo (19b)]. Por outro lado, se o antecedente constitui uma entidade [-animada; -específica] e na construção aparece um verbo 
dinâmico, é possível a variação entre o objeto nulo e o pronome [exemplo (19c)]. As tendências que apontam esta análise qualitativa revelam que, com SNs quantificados, o aspecto lexical dos verbos seria determinante na possibilidade ou não de expressão do objeto pelo pronome.

(19a) L1

((L1 voltando)) eu não encontro a nova fase já saíram dois números da nova fase mas eu fiquei tão decepcionado que eu acho que eu não sei se eu joguei $\emptyset$ fora... ((risos)) mas aqui por exemplo é o número QUArenta e dois não é... deixa eu ver quem já (Informante 5)

(19a') eu não sei eu joguei eles fora

(19b) L1 pelo que eu saiba...a $\mathrm{h} n:$ : . . pelo que eu saiba a FFLCH assim... eu não... eu não tenho ideia de que a FFLCH tenha tido algum reitor na USP

L2 nunca teve $\boldsymbol{\emptyset}$ (Informante 2)

(19b') nunca teve *ele

(19c) L1 ah:: eu... gosto deMAIS (desse aí) eu acho que... desmistiFIca / eu gosto muito desse trabalho sabe... foi uma pesquisa GRANde que nós fizemos eu não publiquei NEM um décimo dos resultados que eu tenho porque o problema que eu também sou uma grande::... como é que a gente fala?... coleto muitos dados ((risos)) L2 ((risos))

L1 e depois eu nem dou conta de... de usar $\emptyset$ sabe... já vou pra outra pesqui::sa [...] (Informante 4)

(19c') depois eu nem dou conta de... de usar eles

No que concerne aos SNs introduzidos pelo artigo indefinido, observamos que com um antecedente [-animado; +específico], em construção com verbo dinâmico, ocorreria a variação entre a omissão do objeto e o pronome [exemplo (20a)]. Quanto a um antecedente [-animado; -específico], se a construção apresenta verbo dinâmico, o pronome também seria aceito [exemplo (20b)]. Entretanto, se o verbo é estativo, o pronome não seria possível [exemplo $(20 \mathrm{c})]$.

(20a) L1 não essa pesquisa terminou porque ago::ra eu tô fazendo uma outra pesquisa que eu comecei agora... que... porque porque primei/eu fi/o::lha são alguns pólos (que teve essa pesquisa)... primeiro é a mulher no mercado de trabalho... que eu queria saber exatamente quais eram as:.... atividades femininas... que não são profissões (né) são ativida::des... mostrar que a mulher não fica trancada só dentro de ca::sa... essa coisa toda que... todo o mito né que se criou:: em torno da mulher... o segundo POlo que deCOrre é essa::... das mulheres... chefiando domicílio... tá... e agora eu tô NO terceiro polo... que é o estudo da... da riqueza feminina então tô estudando os inventá::rios... e:: e procurando ver quais eram os bens que as mulheres possuí::am... se elas tinham mais escravos que os homens ou não ti::nham... se elas... libertavam mais os seus... os seus escravos ou as suas escra::vas... enfim eu tô fazendo... Ø comecei aGOra... essa aí...

(20a') eu tô fazendo ela...

(20b) L1 (eu meio que me) aventurei... a faze...então desde aquela época eu tento faze... as vezes dá certo às vezes num dá....às vezes faço uma letra eles não gostam muito eu refaço Ø... até dá certo né... [...] (Informante 6)

(20b') eu refaço ela

(20c) L1 [...] para:: fazer sua pesquisa... a partir da FAPESP não você passou a ter bolsas... passou a ter auxílios à pesquisa vindas de uma fonte:: externa à sua universidade... e isso com o tempo foi se generalizando... hoje todos o estados do país 
têm uma fundação de amparo à pesquisa... a mais pujante é a de São Paulo... mas TODOS os estados TÊM Ø… do Rio tá muito boa... da Bahia tá muito boa... de Pernambuco tá muito boa... Minas Gerais também... (Informante 3)

(20c') mas TODOS os estados TEM *ela

Conforme vimos, de acordo com Kato (2002), no PB, a elipse do objeto poderia referirse a antecedente [+humano] se este ocorre em posição de tópico. Contudo, encontramos nas entrevistas a ocorrência de um SN [+animado; +específico], que constitui um nome próprio e que foi realizado mediante a elipse em construção com verbo dinâmico e predicação secundária. Nesse caso, é possível a retomada do antecedente pelo pronome.

(21) L1 é mui difíci / olha e::u... a minha orientadora que foi Maria Teresa (Persona) ela ainda é viva...

L2 uhn

L1 quando eu entrei na faculdade eu era muito MOça eu... tinha::.... entrei assim como instrutora voluntária eu tinha vinte e um anos vinte e dois anos ( ) me formei muito jovem né... e ela falou "agora que cê é minha cole::ga... você não vai mais me chamar de senhora" MAGI::na... a vida inteira chamei Ø (Informante 4)

$\left(21^{\prime}\right)$ a vida inteira chamei ela de senhora

No âmbito dos SNs introduzidos por determinantes definidos e [+animados; +específicos], encontramos também outro caso de objeto nulo em construção com verbo cognitivo em que o antecedente não constitui um tópico [exemplo (22a)]. Por outro lado, em (22b), temos uma ocorrência de omissão do objeto com antecedente [+animado; +específico], em construção com verbo cognitivo e tópico. Em ambos os casos é possível a alternância entre a elipse e o pronome.

(22a) L3 e o senhor conheceu sua esposa em toda essa jornada quando?

L1 eu conheci... bom... aí primeiro eu me casei muito jovem não é minha filha sabe não é... me casei com quarenta e cinco quase quarenta e seis anos não é... eu conheci Ø num curso que eu fui fazer no Rio de Janeiro não é... [...] (Informante 7)

(22a') eu conheci ela num curso que eu fui fazer no Rio de Janeiro

(22b) aqui perto do Ipiranga ele me diz "não você pode me deixar aqui que aqui" aí eu "não eu faço questão" "não não eu tenho um negócio aqui" aí que eu entendi falei "esse cara aqui é alguma coisa" e Esse CAra eu conheci Ø depois na morte de um dos caras que foram jogados no rio aqui perto... um cara que era amigo meu que era lá do Rio Grande do Norte não é...

(22b') Esse cara eu conheci ele depois na morte de um dos caras que foram jogados no rio aqui perto

Por fim, também no âmbito dos SNs definidos, encontramos a possibilidade de variação entre pronome e elipse com antecedente [-animado; +específico] [exemplo (23a)] e [-animado; -específico] [exemplo (23b)], com verbo dinâmico. 
(23a) L1 [...] eu acho que o meu trabalho ele é um dos primeiros trabalhos... senão o primeiro né... trabalho que surge na na... trabalho acaDÊmico né... que surge a respeito do assunto... e aí procurei disseminar $\boldsymbol{\emptyset}$ porque eu acho que [...] (Informante 4)

(23a') aí eu procurei disseminar ele

(23b) L1 ((risos)) ( ) é que eu não tô lendo mais os manuscritos porque não dá tempo...daqui a pouco eu já não sei mais ler... Ø ((risos)) (Informante 4)

(23b') daqui a pouco eu já não sei mais ler eles

As tendências que observamos mediante a análise qualitativa dos dados revelam que, no PB, língua que se configura como de objeto nulo, haveria uma gradação na possibilidade de variação entre a elipse e o pronome relacionada à referencialidade do SN antecedente, aos traços semânticos de definitude e indefinitude dos determinantes e ao aspecto lexical do predicado verbal. Nessa língua, os verbos estativos, que expressam uma situação que se manifesta de maneira homogênea (DE MIGUEL, 1999), combinados à indefinitude do determinante e a antecedentes menos referenciais, compreendem contextos linguísticos relacionados à impossibilidade de expressão do objeto mediante o pronome. No espanhol, essa impossibilidade se manifesta com os SNs sem determinante que aparecem em construções com o verbo estativo tener: ¿Tienes cerillas? No tengo Ø (cf. BRUCART, 1999, p. 2805).

Quanto aos dados de objetos nulos detectados na variedade de espanhol de Madri até este momento, observamos que, embora tenhamos encontrado SNs introduzidos por determinante definido, estes apresentam os traços semânticos [-animado; -específico], correspondentes a argumentos menos referenciais. Além disso, as construções em que ocorre o objeto nulo apresentam perífrase verbal e/ou aspecto imperfectivo e verbos de comunicação e cognitivos, que são contextos que atuam na possibilidade de objetos nulos em outras variedades dessa língua (cf. KANY, 1969; LANDA, 1993).

\section{Reflexões sobre o ensino da Língua Espanhola}

Apresentaremos, nesta seção, algumas reflexões sobre o ensino da língua espanhola orientado pelas perspectivas teóricas gerativa (CHOMSKY, 1981; 1986) e sociolinguística (LABOV, 2008; WEINREICH; LABOV; HERZOG, 2009). Primeiro abordaremos alguns aspectos do funcionamento do espanhol comparado ao PB e, em seguida, discutiremos nossa proposta de ensino.

González (1994), em sua tese pioneira e inédita, detectou uma 'inversa assimetria' entre o espanhol e o PB no que se refere à expressão do sujeito e do objeto. Essa pesquisadora teve como ponto de partida a assimetria encontrada por Tarallo (1993) entre o PB e o português europeu. 
Conforme González (1994), no âmbito do sujeito, enquanto a tendência no espanhol seria ao apagamento do pronome, no $\mathrm{PB}$, a tendência seria à realização pronominal. Quanto ao objeto acusativo, no espanhol, a tendência seria ao preenchimento do objeto pelo pronome átono, que poderia ser duplicado pelo tônico por necessidades discursivas, ao passo que, no PB, a tendência seria ao apagamento do objeto e à realização pelo pronome lexical.

Segundo Galves (1993, 2001), essa mudança no PB teria se originado devido ao enfraquecimento da concordância verbal, gerada pela perda da distinção entre a $2^{\mathrm{a}}$ e a $3^{\mathrm{a}}$ pessoa, a partir da inserção do pronome 'você' como forma de tratamento. Galves (1993), apoiada em Chomsky (1981), propõe que teria havido no PB uma mudança paramétrica no âmbito do sistema de concordância verbal. O sistema flexional do PB teria se transformado em um sistema de concordância fraco, que se diferencia pela combinação dos traços 'pessoa' e 'plural'. Por outro lado, uma língua de concordância rica, como o espanhol, apresenta três valores associados ao traço pessoa.

González (1994) apresenta os fenômenos sintáticos que, de acordo com Tarallo (1993), seriam resultado da reorganização do sistema pronominal e da reorganização dos padrões das sentenças, ambos decorrentes do enfraquecimento da concordância verbal. Entre os fenômenos relacionados ao sistema pronominal, estariam a expressão do sujeito e objetos direto e indireto, a possibilidade de indeterminação do sujeito sem o pronome 'se', as construções passivas e de indeterminação com 'se', a colocação pronominal. Quanto aos fenômenos relacionados à ordem das palavras, entre estes estariam o bloqueio da ordem verbo-sujeito nas construções com predicados verbais transitivos e a alteração da ordem de palavras nas interrogativas diretas e indiretas. Vejamos com um pouco mais detalhe cada um desses fenômenos.

Com relação à expressão do sujeito e do objeto acusativo, o PB apresenta maior frequência de sujeitos pronominais e de apagamento do objeto em função acusativa, conforme vimos na seção anterior.

(24) Eu não sei como as pessoas conseguem ouvir o João no telefone. Às vezes eu estou do lado dele e não estou escutando (Ø). Parece que ele não está falando. (SP81-1-K-9/10) (TARALLO, 2018 [1993], p. 64)

De acordo com Fernández Soriano (1999), no espanhol, a possibilidade de ausência do pronome sujeito está relacionada com a riqueza da flexão verbal, que é capaz de identificar as diferentes pessoas gramaticais. Nessa língua, o pronome sujeito ocorreria por necessidades discursivas, de modo que é usado para estabelecer contraste, diferenciando dois ou mais referentes (FANJUL, 2014; LUJÁN, 1999). Observem-se as orações a seguir: 
(25) Trabajas de nueve a cinco todos los días. (FERNÁNDEZ SORIANO, 1999, p. 1224).

(26a) No iré a la estancia.

(26b) Yo no iré a la estancia. (FANJUL, 2014, p. 36).

Conforme vimos, Campos (1986) descreve o espanhol como uma língua na qual os objetos nulos se restringiriam a SNs sem determinante, apesar de outras variedades dessa língua aceitarem essa elipse em contextos mais amplos (LANDA, 1993; SUÑER; YÉPEZ, 1988) e em nosso trabalho (SIMÕES, 2015) termos encontrado objetos nulos também com SNs determinados nas variedades de Madri e Montevidéu.

No $\mathrm{PB}$, vimos que seria possível a expressão do objeto acusativo mediante o pronome lexical, que, segundo Kato (2002), perdeu a restrição a antecedente [+humano] [exemplo (27)]. No espanhol, ao contrário, de acordo com Groppi (2009), apenas o pronome clítico poderia retomar um SN em função de objeto acusativo. O pronome tônico poderia duplicar o clítico nos casos em que é necessário estabelecer contraste entre dois ou mais referentes [exemplos (28)].

(27) Eu não vi ele lá. (GONZÁLEZ, 1994, p. 215).

(28a) *Veo a ella.

(28b) La veo [a ella]. (GROPPI, 2009, p. 100).

A partir da mudança linguística, o PB passou a apresentar a tendência a uma interpretação indeterminada do sujeito em construções sem o pronome 'se'. No espanhol, entretanto, uma construção assim receberia uma interpretação referencial, já que, conforme Fanjul (2014), para que seja possível a interpretação indeterminada, seria necessário o pronome 'se' ou a $3^{\mathrm{a}}$ pessoa do plural.

(29) "Não usa mais saia"

Português do Brasil: Não se usa mais saia.

Português de Portugal: Alguém não usa mais saia. (TARALLO, 2018 [1993], p. 66).

- ¿Aquí se hace/hacen cambio de domicilio?

— Sí./ Sí, lo hacemos. / Sí, se hace. (FANJUL, 2014, p. 48).

Quanto à expressão do objeto indireto, segundo Torres Morais e Berlinck (2007), os pronomes 'lhe'/'Ihes' apresentam baixa ocorrência na fala e escrita menos formais no PB e haveria a tendência ao uso da preposição 'para' em detrimento de 'a' para introduzir o objeto indireto.

(31a) Por favor, MANDEM UM RECADO AO CAETANO VELOSO. No número 196 de CAPRICHO, ele diz que se acha muito feio. O recado é este: Caetano, você é lindo. (Capricho, 04/1968, p. 42).

(31b) Vá voando para a cozinha, crie uma receita deliciosa que use o azeite do coração e MANDE PARA A GENTE. (Claudia, 2/1997, p. 33) (TORRES MORAIS; BERLINCK, 2006, p. 68). 
Por outro lado, no espanhol, o objeto indireto anafórico se expressa pelos pronomes átonos e pode ser duplicado por um pronome tônico por necessidades discursivas (FERNÁNDEZ SORIANO, 1999).

(32) Le di el regalo a él (*di el regalo a él). (FERNÁNDEZ SORIANO, 1999, p. 1248).

No $\mathrm{PB}$, a reorganização do sistema pronominal também está associada à diminuição na frequência dos pronomes reflexivos e do pronome 'se' nas construções inacusativas. Por outro lado, no espanhol, de acordo com Fanjul (2014), é necessária a presença do clítico nas construções reflexivas [exemplos (33)] e nas inacusativas [exemplos (34) e (35)].

(33a) $\mathrm{Eu}(\mathrm{me})$ vejo a mim mesmo nele.

(33b) Me veo (a mí mismo) en él. (FANJUL, 2014, p. 47).

(34a) A gelatina amoleceu.

(34b) La gelatina se ablandó.

(35a) Quero (me) levantar cedo.

(35b) Quiero levantarme temprano. (FANJUL, 2014, p. 48).

Em relação às orações passivas com o pronome 'se', conforme Araújo Jr. (2014), no $\mathrm{PB}$, predominam as passivas de particípio [exemplos (36)], enquanto no espanhol há um predomínio das passivas com 'se' [exemplos (37)]. Segundo Nunes $\left(1990^{6}\right.$, apud GONZÁLEZ, 1994), haveria uma tendência no PB à diminuição da concordância nas estruturas com o pronome 'se', de modo que esse pronome passaria a ser interpretado como indeterminado ao invés de apassivador [exemplo (38)].

(36a) O refém foi libertado após o pagamento do resgate.

(36b) El atracador fue detenido por la policía al intentar fugarse.

(37a) Segundo as estatísticas do governo, este ano compraram-se mais geladeiras, fogões e máquinas de lavar que no ano passado.

(37b) Se han aprobado leyes que dificultan la inmigración. (ARAÚJO JR., 2014, p. 134).

(38) Vende-se casas. (GONZÁLEZ, 1994, p. 216).

No que se refere à mudança na colocação dos pronomes clíticos, conforme Galves (2001), no PB, o pronome aparece como próclise ao verbo principal (exemplos (39)]. Por outro lado, no espanhol, de acordo com González (1994), nas perífrases com os verbos principais no infinitivo ou gerúndio, o pronome pode aparecer como ênclise ao verbo principal ou como próclise ao verbo auxiliar [exemplos (40)].

(39a) João queria the falar. (GONZÁLEZ, 1994, p. 216).

(39b) Agora não tinha me lembrado (POA - Did). (GALVES, 2001, p. 134).

${ }^{6}$ NUNES, J. O famigerado 'se'. Uma análise diacrônica das construções com 'se' apassivador e indeterminador. 1990. Dissertação de Mestrado, IEL/Unicamp, Campinas, fev. 1990, inédita. 
(40a) Quiero verte.

(40b) Te quiero ver. (GONZÁLEZ, 1994, p. 171).

Com respeito aos fenômenos que integram a reorganização dos padrões das construções, no $\mathrm{PB}$, a ampliação da possibilidade de objetos nulos teria gerado o bloqueio da ordem verbosujeito nas construções transitivas e, como consequência, a ordem padrão no PB passou a ser sujeito-verbo-objeto.

(41) Cadê o pronome? O gato comeu (e). (GONZÁLEZ, 1994, p. 217).

Outro fenômeno vinculado à organização das sentenças constitui a alteração da ordem dos constituintes nas perguntas diretas e indiretas, que no PB passou a ser sujeito-verbo. Por outro lado, no espanhol, conforme Zubizarreta (1999), o pronome deve aparecer posposto ao verbo nas orações interrogativas diretas e indiretas. Observem-se as construções a seguir:

(42a) O que o João comprou?

(42b) Me pergunto o que o João comprou?

(43a) ¿Qué compró Juan?

(43b) * ¿Qué Juan compró?

(44a) Me pregunto qué compró Juan.

(44b) *Me pregunto qué Juan compró. (ZUBIZARRETA, 1999, p. 4217).

Realizada essa abordagem sobre as diferenças no funcionamento do espanhol e do PB, iniciaremos nossa reflexão sobre o ensino da língua espanhola no curso de Letras da Universidade Federal de Alfenas, situada no sul do estado de Minas Gerais.

Todos os semestres, para cada uma das disciplinas que somos responsáveis de ministrar, inserimos no programa do curso que a abordagem do ensino do funcionamento da língua espanhola será orientado pelas perspectivas teóricas gerativa (CHOMSKY, 1981; 1986) e sociolinguística (LABOV, 2008; WEINREICH; LABOV; HERZOG, 2009) ${ }^{8}$. No primeiro dia de aula, apresentamos alguns dos conceitos dessas teorias. Também nos apoiamos nas reflexões de Kulikowski (2015) e Celada e González (2015), que nos proporcionam uma incursão pela história do espanhol no Brasil.

Nosso intuito ao abordar essas teorias em nossa prática docente é que, ao ter contato com a gramática e o funcionamento do espanhol, o aluno tenha uma visão de língua como um conhecimento internalizado, que sofre variação e está condicionada por fatores linguísticos e sociais.

${ }^{7}$ As orações em (42) foram elaboradas por nós.

${ }^{8}$ Como as disciplinas têm por objetivo o desenvolvimento das quatro habilidades linguísticas em língua espanhola, sendo estas a compreensão e expressão oral e escrita, nos apoiamos também na perspectiva dos gêneros discursivos de Bakhtin (VARGENS; FREITAS, 2010). 
No primeiro e segundo dias de aula da disciplina de 'Língua Espanhola I', nos valemos do enunciado ‘¿Cómo te llamas?’’, que o aluno empregará para perguntar o nome ao seu interlocutor de maneira informal, e perguntamos aos alunos como faríamos para perguntar o nome no PB. Imediatamente, aparece a construção 'Como você (se) chama?'. Pedimos, então, que observem as diferenças e semelhanças entre as duas construções. Algumas das observações são a flexão de pessoa e número presente no verbo em espanhol e a ausência nessa língua de um pronome correspondente ao 'você'.

Após essas primeiras reflexões, perguntamos a eles se poderíamos excluir o pronome 'você' do enunciado do PB e, ainda assim, perguntar o nome de nosso interlocutor, como em '??Como (se) chama?'. A resposta dos alunos é negativa. Nessa oportunidade, explicamos que esse seria o conhecimento internalizado que nós, como falantes do $\mathrm{PB}$, teríamos e que se trata de um conhecimento adquirido naturalmente desde a infância, sem necessidade de nenhum tipo de aprendizagem formal.

Nosso objetivo seria que eles compreendessem, a partir de sua experiência sobre a língua materna, o que seria a gramática internalizada. Explicamos também sobre o processo de variação e mudança linguística pelo qual vem passando o PB e que, como vimos, o diferenciou do espanhol. Esclarecemos sobre o enfraquecimento da concordância no PB (GALVES, 2001) e que, no espanhol, a desinência de pessoa e número $-s$ seria suficiente, nesse caso, para identificar a pessoa gramatical.

A partir da construção '??Como (se) chama?', que causaria um estranhamento entre os falantes do PB caso o objetivo seja perguntar o nome ao interlocutor, explicamos aos alunos que esta seria perfeitamente possível se o sujeito da oração tiver como referente uma entidade [-animada], presente no contexto situacional ou até mesmo discursivo. Conforme nossa intuição de falante do PB, pensamos que, se o referente fosse [+animado], o pronome seria necessário ('Como ele/ela (se) chama?') ${ }^{10}$.

\footnotetext{
${ }^{9}$ Mais adiante no curso, o aluno entra em contato com o fenômeno do 'voseo', de modo que, nessa ocasião, aprende que para perguntar o nome do interlocutor de maneira informal nas variedades em que ocorre esse fenômeno se diz ‘¿Cómo te llamás?'. Conforme Fontanella de Weinberg (1999), Argentina, Paraguai e Costa Rica se incluem entre os países em que esse fenômeno é generalizado. Por outro lado, no Uruguai essa forma está condicionada pelo grau de intimidade entre os interlocutores e, no Chile, pelo registro e escolaridade do falante.

${ }^{10}$ Encontramos, no metrô de São Paulo, um enunciado de uma publicidade sobre o filme $A$ família Addams, que se observa em (1):
}

(1) “Acha que a sua família é esquisita?"

Nesse enunciado, o sujeito da oração principal está elíptico. Nossa hipótese é de que esse sujeito nulo seria possível devido ao fato de 'achar' ser um predicado verbal de estado e cognitivo. Além disso, embora o enunciado esteja dirigido a um interlocutor, não se trata exatamente de um interlocutor específico, já que a publicidade é direcionada às diversas pessoas que transitam diariamente pelo metrô de São Paulo. Observamos também que, após efetuarmos uma compra com cartão, a atendente nos perguntou, 'Quer sua via?', ao invés de 'Você quer sua via?'. Nesse caso, 
Seguimos com essa primeira reflexão sobre o funcionamento do espanhol em comparação com o do PB e chamamos a atenção dos alunos sobre a possibilidade, no PB, de variação na expressão do pronome reflexivo: 'Como você (se) chama?'. Por outro lado, esclarecemos que, no espanhol, é necessária a expressão do pronome reflexivo. Se esse pronome estiver ausente, como em ‘Cómo llamas?', explicamos aos alunos que um falante nativo não compreenderá que perguntamos o seu nome. $\mathrm{O}$ falante nativo poderia nos perguntar ‘Cómo llamo qué?’, já que a ausência do pronome reflexivo geraria a necessidade de um objeto direto.

Abordamos também a questão da presença do pronome sujeito em espanhol. Explicamos aos alunos que, se o pronome estiver presente, deverá, nas orações com elementos interrogativos, aparecer depois do verbo, de modo que a ordem seja verbo-sujeito, como em ‘¿Cómo te llamas tú?’. Esclarecemos que a ordem sujeito-verbo seria possível em algumas variedades da língua espanhola de determinadas regiões, mas considerada agramatical em outras.

Em relação à presença do pronome, explicamos que este apareceria nas situações em que é necessário expressar contraste (FANJUL, 2014; FERNÁNDEZ SORIANO, 1999). Portanto, se me dirijo a um interlocutor e pergunto a ele ‘¿Cómo te llamas tú?’, a minha intenção é saber o nome dele, não o nome de uma ou mais pessoas presentes no ambiente. Esclarecemos aos alunos que a construção correspondente no PB seria 'Como VOCÊ (se) chama?', com o pronome sujeito sendo produzido com um acento enfático, tendo, nesse caso, o mesmo efeito de sentido da construção com a presença do pronome sujeito no espanhol.

A partir de todas essas explicações sobre a língua espanhola e comparações com a língua materna dos estudantes realizadas nos primeiros dias de aula, buscamos levar os alunos à reflexão sobre o que seria o conhecimento linguístico internalizado e a variação linguística, que está condicionada tanto por fatores linguísticos quanto sociais, como região geográfica, idade, escolaridade, entre outros. É um momento de sensibilizá-los, logo no início do processo de aquisição/aprendizagem, a respeito do funcionamento particular da gramática do espanhol.

Conforme Kulikowski (2015, p. 49-50), entre os aspectos implicados no ensino do espanhol no Brasil, estariam:

[...] elementos que tienen que ver con el estudio de los sistemas gramaticales en juego y los procesos de adquisición/aprendizaje; aspectos que aproximan y

temos a possibilidade de sujeito nulo, com referente [+animado; +específico], sendo o verbo da construção estativo e cognitivo. É possível que a semântica do verbo tenha um papel relevante na possibilidade de omissão do pronome sujeito, já que, segundo o estudo de Duarte (2018 [1993]), a $1^{\mathrm{a}}$ e a $2^{\mathrm{a}}$ pessoas do discurso seriam as que mais tenderiam a expressar o sujeito mediante o pronome. 
diferencian ambas lenguas, español y portugués; [...] el estudio, a partir de diversas líneas teóricas, de la producción de sentido(s) y de efectos de sentido que auxilian en la lectura de las diversas discursividades presentes en las lenguas.

Com a reflexão que buscamos promover em nosso curso, que passa pelas diferentes construções que, conforme González (1994), apresentam uma 'inversa assimetria' entre o espanhol e o PB, nosso objetivo é que o aluno possa perceber, a partir do estudo das especificidades do espanhol, o diferente efeito de sentido que gera a presença ou a ausência do pronome sujeito (‘¿Cómo te llamas?’/’¿Cómo te llamas tú?’), a ausência do pronome reflexivo (‘¿Cómo llamo qué?’) e a ordem sujeito-verbo em orações com elementos interrogativos, que seria possível em algumas regiões, mas seria agramatical em outras ('*¿Cómo tú te llamas?’`¿¿Cómo te llamas tú?’).

Em sua crítica sobre o ensino da língua espanhola no Brasil, que durante muito tempo se apoiou na crença da semelhança entre as duas línguas, González (CELADA; GONZÁLEZ, 2015, p. 75) afirma que:

Pocas veces se considera lo que está por detrás de la superficial semejanza de las formas, la ilusión de comprensión que produce la semejanza formal, eso mismo que hace que se multipliquen, como dice Revuz (1998), los diálogos entre sordos y las situaciones grotescas en las que no se comprende lo suficiente para comprender que no se comprende.

Tendo em vista essa reflexão de González, consideramos importante a sensibilização sobre o funcionamento do espanhol comparado com o do PB logo no início da aquisição/aprendizagem do espanhol, já que, conforme discorrem essas autoras, está no imaginário dos brasileiros a ideia do espanhol como uma língua fácil, que não valeria a pena estudar e que as dificuldades estariam, por exemplo, nos falsos cognatos. Após nossa abordagem do ensino, uma aluna relatou que compreendeu por que, em uma viagem ao Chile, havia perguntando a um moço chileno ‘¿Cómo tú llamas?’, com a intenção de saber o seu nome, e este não havia entendido a pergunta.

A partir da reflexão de González (CELADA; GONZÁLEZ, 2015) e desse caso que relatamos, é possível observar que, partindo desse imaginário sobre a língua espanhola, a tendência seria o aluno, conduzido pela semelhança das formas, realizar traduções ao espanhol considerando o funcionamento do $\mathrm{PB}$, o que poderia gerar construções agramaticais como ‘*¿Cómo tú llamas?’ e que acarretariam sérios problemas na comunicação.

Em relação ao ensino do objeto em função acusativa, nesses primeiros dias de aula para a disciplina de 'Língua Espanhola I', fazemos uma breve reflexão a respeito do tema. 
Explicamos aos alunos que, enquanto no espanhol um referente como 'el libro' seria retomado mediante o pronome clítico, como em 'Compré el libro, pero todavía no lo leí', no PB, seria possível uma elipse para expressar o referente 'o livro' ou o pronome lexical, como em 'Eu comprei o livro, mas eu ainda não li Ø/ele'. Comentamos, nessa ocasião, sobre a possibilidade de objetos nulos em algumas variedades do espanhol que estão em contato com línguas indígenas e com o basco (LANDA, 1993; SUÑER; YÉPEZ, 1988).

Por outro lado, perguntamos a eles se seria possível que compreendêssemos que foi Maria que o falante do enunciado não viu em uma sentença como 'A Maria estava na festa, mas eu não vi * Ø/ela' se considerarmos a elipse. Imediatamente as respostas que aparecem é que seria possível compreender que foi Maria que o falante não viu apenas no caso da retomada pelo pronome, pois a ausência deste leva à interpretação de um antecedente oracional ('Não vi que ela estava na festa'). Fazemos a reflexão, então, de que, embora o PB apresente uma ampla possibilidade de objetos nulos, ocorrem restrições na esfera dos antecedentes [+animados; +específicos] e que, assim como não compreendemos que nos referíamos à Maria no caso da elipse, um falante nativo do espanhol não compreenderia se omitíssemos o pronome com um antecedente como 'María' ou 'el libro' em função acusativa, uma vez que as restrições nessa língua ocorrem também com antecedentes [-animados; +/-específicos].

A partir de mais essa reflexão, nosso objetivo é que o aluno capte a noção de conhecimento linguístico internalizado. No caso do espanhol, o pronome clítico seria incorporado na gramática do espanhol mediante aquisição natural, de modo que inclusive falantes sem escolaridade os produzem (FANJUL, 1999). No PB, ao contrário, o objeto nulo e o pronome lexical integram a gramática internalizada, que se forma por aquisição natural, enquanto o pronome clítico é incorporado mediante aprendizagem formal (GALVES, 2001; KATO, 2005).

Um pouco mais adiante nessa disciplina, propomos um exercício de reflexão linguística a partir do enunciado a seguir, extraído do jornal espanhol El País.

(42) "Ya llegué a dar a los niños esa agua. La herví y la colé. No teníamos otra", reconoce avergonzada Andreia. (El país, 18/05/2015)

Esclarecemos aos alunos que o enunciado original foi produzido por uma falante do PB, que foi entrevistada para uma reportagem a respeito da crise hídrica em São Paulo e, posteriormente, foi traduzido para o espanhol. Em seguida, pedimos a eles que tentem reproduzir o enunciado original da mulher entrevistada, sendo as possibilidades: 'Eu já cheguei a dar aos meninos essa água. Eu fervi $\emptyset$ e coei Ø/ela'. A partir desse resultado, refletimos com 
os alunos sobre a possibilidade de omissão do objeto no PB e sua necessidade de expressão no espanhol. Nesse sentido, faria parte da gramática do espanhol a retomada do referente 'essa água', que seria [-animado], mediante o pronome clítico. Nesse caso, temos a tradução de uma entrevista na modalidade oral, que é representada na modalidade escrita da língua, mas, ainda assim, reproduziria um discurso oral, que, conforme vimos a partir do resultado de nossa pesquisa (SIMÕES, 2015), em determinados contextos poderiam expressar-se mediante a elipse.

Em outro exercício, pedimos aos alunos que observem em um fragmento da reportagem La historia de Rubio, el perro callejero argentino adoptado por una azafata alemana, também extraído do jornal El País, a que entidades se referem os pronome clíticos em destaque. Em seguida, pedimos que eles identifiquem o referente dos pronomes 'la' e 'ella' na oração que aparece sublinhada no final do fragmento, expliquem o fenômeno que ocorre e o que expressa.

"La historia comenzó el 9 de octubre del año pasado, cuando en una de las recorridas que hacemos cada día vemos al perro", dice Ariel Rota, voluntario de la ONG que opera en Puerto Madero. "Era nuevo, mandamos fotos a las redes por si estaba perdido y nadie lo conocía. Lo llamamos Cola corta, porque la tiene cortada. El tipo venía, desaparecía, volvía a aparecer. Cada vez que volvía le dábamos de comer pero no hubo nadie que pudiese agarrarlo. En julio nos contacta Olivia y nos cuenta que ella veía un perrito cada vez que viajaba a Buenos Aires. Dijimos: ‘¿Es Cola corta!”.

Para ese entonces la organización ya tenía un candidato para Rubio, un joven llamado Nicolás propuso llevárselo a su casa. "Nos encontramos en el hotel con Nicolás y con Olivia. Ahí, como por arte de magia, la mujer pudo agarrar a Rubio. En 5 minutos nos dimos cuenta de que Rubio la quería sólo a ella", explica Ariel, pero la mujer aún no había manifestado su intención de adoptarlo.

O objetivo, nessa segunda parte do exercício, é levar o aluno à reflexão sobre a necessidade do uso do pronome tônico 'ella', que deve ser introduzido pela preposição 'a', para expressar contraste, ou seja, para referir-se em particular a um referente e não a outros presentes no contexto discursivo. É importante que o aluno perceba que esse uso do pronome tônico se restringe às entidades [+humanas] (GROPPI, 2009).

\section{Considerações finais}

Apresentamos, neste artigo, os resultados iniciais de nossa atual pesquisa sobre o objeto pronominal acusativo de $3^{\mathrm{a}}$ pessoa na variedade de espanhol de Madri e no PB, bem como tecemos reflexões sobre o ensino da língua espanhola tendo em vista os avanços na descrição linguística do espanhol e as perspectivas teóricas gerativa (CHOMSKY, 1981; 1986) e sociolinguística (LABOV, 2008; WEINREICH; LABOV; HERZOG, 2009). 
Vimos que, embora o espanhol seja descrito como uma língua altamente restringida para a ocorrência de objetos nulos (CAMPOS, 1986; FERNÁNDEZ SORIANO, 1999; GROPPI, 1997), algumas variedades dessa língua aceitam a omissão do objeto em contextos mais amplos e, em nossa pesquisa de doutorado (SIMÕES, 2015), observamos a possibilidade de elipse nas variedades de Madri e Montevidéu condicionada tanto pela estrutura e traços semânticos do SN quanto pela estrutura e semântica da construção. Em nossa atual pesquisa, os resultados iniciais sobre o espanhol apontam para as tendências já observadas em nosso trabalho anterior (SIMÕES, 2015), e o mesmo ocorre no âmbito do PB, língua em que o pronome lexical já não seria aceito com SNs que apresentam o traço semântico de indefinitude e em construções estativas.

Com relação ao ensino da língua espanhola, nossa ideia é de que o avanço dos estudos descritivos e sua abordagem no ensino a partir da dessas perspectivas teóricas permitam ao aluno refletir sobre o funcionamento do espanhol, comparando-o com o de sua língua materna, para que este comece a compreender os condicionadores linguísticos e sociais que estão envolvidos na possibilidade de omissão ou na necessidade da presença de pronome.

\section{REFERENCIAS}

ARAÚJO JR, B. As formas passivas. In: FANJUL, A.; GONZÁLEZ, N. M. (org.). Espanhol e português brasileiro: estudos comparados. São Paulo, Parábola, 2014. p. 133-157.

BRUCART, J. M. La elipsis. In: BOSQUE, I.; DEMONTE, V. (org.). Gramática descriptiva de la lengua española. Madrid: Espasa, 1999. p. 2787-2866.

CAMPOS, H. Indefinite object drop. Linguistic Inquiry, Estados Unidos, v. 17, n. 3, p. 354359, 1986.

CAMPOS, H. Transitividad e intransitividad. In: BOSQUE, I.; DEMONTE, V. (org.). Gramática descriptiva de la lengua española. Madrid: Espasa, 1999. p. 1519-1574.

CARDINALETTI, A; STARKE, M. The typology of structural deficiency: on three grammatical classes. Working paper in linguistics, University of Venice, v. 4, n. 2, p. 41109, 1994.

CASAGRANDE, S. Restrições de ocorrência do objeto direto anafórico no português brasileiro: gramática adulta e aquisição da linguagem. ReVEL [online], n. 6, p. 131-163, 2012.

CELADA, M. T.; GONZÁLEZ, N. M. El español en Brasil: un intento de captar el orden de la experiencia. In: SEDYCIAS, J. (org.). O ensino do espanhol no Brasil. Passado, presente, futuro. São Paulo: Parábola, 2015. p. 71-96. 
CESTERO MANCERA, A. M. et al. La lengua hablada en Madrid. Corpus PRESEEA Madrid (Distrito de Salamanca). Hablantes de instrucción superior. Alcalá de Henares: Universidad de Alcalá, 2014. v. I.

CHOMSKY, N. Lectures on governing and binding. Dordrecht: Foris, 1981.

CHOMSKY, N. Knowledge of Language: its nature, origin and use. New York: Praeger, 1986.

CYRINO, S. Observações sobre a mudança diacrônica no português do Brasil: objeto nulo e clíticos. In: ROBERTS, I.; KATO, M. (org.). Português brasileiro: uma viagem diacrônica. Campinas, SP: Editora da Unicamp, 1993. p. 163-184.

CYRINO, S. O objeto nulo no português do Brasil: um estudo sintático diacrônico. Orientador: Mary A. Kato. 1994. 227 f. Tese (Doutorado em Ciências) - Universidade Estadual de Campinas, Campinas, 1994. Disponível em:

http://www.repositorio.unicamp.br/handle/REPOSIP/270355. Acesso em: 19 jul. 2018.

CYRINO, S. O objeto nulo do português brasileiro. DELTA [online], Pontifícia Universidade Católica de São Paulo, v. 12, n. 2, p. 221-238, 1996.

CYRINO, S.; DUARTE, M. E.; KATO, M. Visible subjects and invisible clitics in Brazilian Portuguese. In: NEGRÃO, E.; KATO, M. (org.). Brazilian Portuguese and the null subject parameter. Madrid, Frankfurt: Iberoamericana/Vervuert, 2000. p. 55-73.

DE MIGUEL, E. El aspecto léxico. In: BOSQUE, I.; DEMONTE, V. (org.). Gramática descriptiva de la lengua española. Madrid: Espasa, 1999. p. 2977-3060.

DI TULLIO, Á. Manual de gramática del español. Buenos Aires: Edicial, 1997.

DUARTE, M. E. Variação e sintaxe: clítico acusativo, pronome lexical e categoria vazia no português do Brasil. 1986. 73 f. Dissertação (Mestrado) - Pontifícia Universidade Católica de São Paulo, São Paulo. 1986.

FANJUL, A. Espacio de la persona en la versión portugués-español: un problema de identidad discursiva. Estudos Acadêmicos UNIBERO, São Paulo, v. 10, p.135-154, jul./dez. 1999.

FANJUL, A. Conhecendo assimetrias: a ocorrência de pronomes pessoais. In: FANJUL, A.; GONZÁLEZ, N. M. (org.). Espanhol e português brasileiro: estudos comparados. São Paulo, Parábola, 2014. p. 29-50.

FERNÁNDEZ SORIANO, O. El pronombre personal. Formas y distribuciones. Pronombres átonos y tónicos. In: BOSQUE, I.; DEMONTE, V. (org.). Gramática descriptiva de la lengua española. Madrid: Espasa, 1999. p. 1209-1273.

FONTANELLA DE WEINBERG, M. B. Sistemas pronominal de tratamiento usados em el mundo hispânico. In: BOSQUE, I.; DEMONTE, V. (org.). Gramática descriptiva de la lengua española. Madrid: Espasa, 1999. p. 1399-1425. 
GALVES, C. O enfraquecimento da concordância no português brasileiro. In: ROBERTS, I.; KATO, M. (org.). Português brasileiro: Uma viagem diacrônica. Campinas, SP: Editora da Unicamp, 1993. p. 387-408.

GALVES, C. Ensaios sobre as gramáticas do português. Campinas: Ed. da Unicamp, 2001.

GONZÁLEZ, N. M. Cadê o pronome? O gato comeu. Os pronomes pessoais na aquisição/aprendizagem do espanhol por brasileiros adultos. Orientadora: Diana Luz Pessoa de Barros. 1994. 451 f. Tese (Doutorado) - Universidade de São Paulo, São Paulo, 1994. Disponível em: http://dlm.fflch.usp.br/neide-therezinha-maia-gonzalez. Acesso em: dez. 2019.

GROPPI, M. Pronomes pessoais no português do Brasil e no espanhol do Uruguai. 1997. 152 f. Tese (Doutorado) - Universidade de São Paulo, São Paulo, jun. 1997.

GROPPI, M. Estructuras con clíticos: revisión de terminología y datos del español. Signo y Seña, Buenos Aires, n. 20, p. 95-113, 2009.

KANY, C. Sintaxis hispanoamericana. Madrid: Gredos, 1969.

KATO, M. Pronomes fortes e fracos na sintaxe do Português Brasileiro. Revista Portuguesa de Filologia, Coimbra, Portugal, v. XX, p. 101-122, 2002.

KATO, M. Null objects ans VP ellipsis in European and Brazilian Portuguese. In: QUER, J. et al. (Eds.). Romance languages and linguistic theory. Amsterdam: John Benjamins, 2003. p. 135-158.

KATO, M. A gramática do letrado: questões para a teoria gramatical. In: MARQUES, M. A., et al. (org.). Ciências da linguagem: trinta anos de investigação e ensino. Braga: CEHUM (Universidade do Minho), 2005. p. 131-145.

KATO, M.; TARALLO, F. Anything you can do in brazilian portuguese. In: JAEGGLI, O.; SILVA-CORVALÁN, C. (org.). Studies in romance linguistics. Dordrecht: Foris, 1986. p. 346-358.

KULIKOWSKI, M. Z. La lengua española en Brasil: un futuro promisor. In: SEDYCIAS, J. (org.). O ensino do espanhol no Brasil. Passado, presente, futuro. São Paulo: Parábola, 2015. p. $45-52$.

LABOV, W. Padrões sociolingüísticos. São Paulo: Parábola Editorial, 2008.

LANDA, A. Los objetos nulos determinados del español del País Vasco. Lingüística, Espanha, n. 5, p. 131-146, 1993.

LEONETTI, M. El artículo. In: BOSQUE, I.; DEMONTE, V. (org.). Gramática descriptiva de la lengua española. Madrid: Espasa, 1999. p. 787-890.

LIGHTFOOT, D. How new languages emerge. New York: Cambridge, 2006. 
LIMA-HERNANDES, M. C.; VICENTE, R. (org.). A língua portuguesa falada em São Paulo: amostra da variedade culta do século XXI. São Paulo: Humanitas, 2012.

LUJÁN, M. Expresión y omisión del pronombre personal. In: BOSQUE, I.; DEMONTE, V. (org.). Gramática descriptiva de la lengua española. Madrid: Espasa, 1999. p. 1275-1316.

MAGALHÃES, T. O sistema pronominal sujeito e objeto na aquisição do português europeu e do português brasileiro. Orientadora: Charlotte Marie Chambelland Galves. 2006. 175 f. Tese (Doutorado em Lingüística) - Universidade Estadual de Campinas, Campinas, 2006.

SIMÕES, A. M. O objeto pronominal acusativo de $3^{\text {a }}$ pessoa nas variedades de espanhol de Madri e Montevidéu comparado ao português brasileiro: clíticos como manifestação visível e objetos nulos como manifestação não visível da concordância de objeto.

Orientadora: Neide Therezinha Maia González. 2015. 386 f. Tese (Doutorado em Letras) Universidade de São Paulo, São Paulo, 2015. Disponível em:

http://www.teses.usp.br/teses/disponiveis/8/8145/tde-09092015-175408/pt-br.php. Acesso em: 10 dez. 2019.

SUÑER, M.; YÉPEZ, M. Null definite objects in Quiteño. Linguistic Inquiry, Estados Unidos, v. 14, p. 561-565, 1988.

TARALLO, F. Sobre a alegada origem crioula do português brasileiro: mudanças sintáticas aleatórias. In: ROBERTS, I.; KATO, M. (org.). Português brasileiro: uma viagem diacrônica. Campinas, SP: Editora da Unicamp, 1993. p. 35-68.

TORRES MORAIS, M. A.; BERLINCK, R. "Eu disse pra ele" ou "Disse-lhe a ele": a expressão do dativo nas variedades brasileira e européia do português. In: CASTILHO, A. T. et al. (org.). Descrição, história e aquisição do português brasileiro. São Paulo: Pontes, 2007. p. 61-83.

VARGENS, D. P. M.; FREITAS. L. M. A. Ler e escrever: muito mais que unir palavras. In: BARROS, C. S.; MARINS-COSTA, E. G. (org.). Espanhol: ensino médio. 1. ed. Brasília: Ministério da Educação, Secretaria de Educação Básica, 2010. v. 16, p. 191-220.

WEINREICH, U.; LABOV, W.; HERZOG, M. Fundamentos empíricos para uma teoria da mudança lingüística. 2. ed. São Paulo: Parábola Editorial, 2009.

ZUBIZARRETA, M. L. Las funciones informativas: Tema y foco. In: BOSQUE, I.; DEMONTE, V. (org.). Gramática descriptiva de la lengua española. Madrid: Espasa, 1999. p. $4215-4244$. 
Como referenciar este artigo:

MARTINS SIMÕES, A. A descrição linguística e sua abordagem no ensino da língua espanhola. Rev. EntreLínguas, Araraquara, v. 6, n. 2, p. 266-297, jul./dez., 2020. e-ISSN: 2447-3529. DOI: https://doi.org/10.29051/el.v6i2.13181

Submetido em: 09/12/2019

Aprovado em: 30/04/2020

Publicado em: 30/09/2020 